\title{
Clinical applications of mesenchymal stem cells
}

\author{
Shihua Wang, Xuebin Qu and Robert Chunhua Zhao*
}

\begin{abstract}
Mesenchymal stem cells (MSC) have generated a great amount of enthusiasm over the past decade as a novel therapeutic paradigm for a variety of diseases. Currently, MSC based clinical trials have been conducted for at least 12 kinds of pathological conditions, with many completed trials demonstrating the safety and efficacy. This review provides an overview of the recent clinical findings related to MSC therapeutic effects. Roles of MSCs in clinical trials conducted to treat graft-versus-host-disease (GVHD) and cardiovascular diseases are highlighted. Clinical application of MSC are mainly attributed to their important four biological properties- the ability to home to sites of inflammation following tissue injury when injected intravenously; to differentiate into various cell types; to secrete multiple bioactive molecules capable of stimulating recovery of injured cells and inhibiting inflammation and to perform immunomodulatory functions. Here, we will discuss these four properties. Moreover, the issues surrounding clinical grade MSCs and principles for MSC therapeutic approaches are also addressed on the transition of MSCs therapy from bench side to bedside.
\end{abstract}

\section{Introduction}

Stem cells have the capacity to self-renew and to give rise to cells of various lineages. Thus, they represent an important paradigm of cell-based therapy for a variety of diseases. Broadly speaking, there are two main types of stem cells, embryonic and non-embryonic. Embryonic stem cells (ESCs) are derived from the inner cell mass of the blastocyst and can differentiate into cells of all three germ layers. However teratoma formation and ethical controversy hamper their research and clinical application. On the other hand, non-embryonic stem cells, mostly adult stem cells, are already somewhat specialized and have limited differentiation potential. They can be isolated from various tissues and are currently the most commonly used seed cells in regenerative medicine. Recently, another type of nonembryonic stem cells, known as induced pluripotent stem cell (iPSC) has emerged as a major breakthrough in regenerative biology. They are generated through enforced expression of defined transcription factors, which reset the fate of somatic cells to an embryonic stem-cell-like state.

Cellular therapy has evolved quickly over the last decade both at the level of in vitro and in vivo preclinical research and in clinical trials. Embryonic stem cells and non-

\footnotetext{
* Correspondence: chunhuaz@public.tpt.tj.cn

Institute of Basic Medical Sciences \& School of Basic Medicine, Center of Excellence in Tissue Engineering, Chinese Academy of Medical Sciences \& Peking Union Medical College, 5\# Dongdansantiao, Beijing, 100005, P.R. China
}

embryonic stem cells have all been explored as potential therapeutic strategies for a number of diseases. One type of adult stem cells, mesenchymal stem cells, has generated a great amount of interest in the field of regenerative medicine due to their unique biological properties. MSCs were first discovered in 1968 by Friedenstein as an adherent fibroblast-like population in the bone marrow capable of differentiating into bone [1]. It was subsequently shown that MSCs can be isolated from various tissues such as adipose tissue, peripheral blood, umbilical cord and placenta. These cells have a remarkable capacity of extensive in vitro expansion which allows them to rapidly reach the desired number for in vivo therapy [2]. Different laboratories have identified, under partly different isolation or culture conditions, MSCs with specific properties. For better characterization of MSC, in 2006, the International Society of Cellular Therapy defined MSCs by the following three criteria [3]:

(1)MSCs must be adherent to plastic under standard tissue culture conditions;

(2) MSCs must express certain cell surface markers such as CD73, CD90, and CD105, and lack expression of other markers including CD45, CD34, CD14, or CD11b, CD79alpha or CD19 and HLA-DR surface molecules;

(3)MSCs must have the capacity to differentiate into osteoblasts, adipocytes, and chondroblasts under in vitro conditions.

\section{Biomed Central}


This review will provide an overview of the recent clinical findings related to MSCs. Roles of MSCs in clinical trials conducted to treat GVHD and cardiovascular diseases are highlighted. The therapeutic effects of MSC are mainly attributed to their four important biological properties. Here, we will discuss these four properties and the issues surrounding use of MSCs that need to be addressed during the transition of MSCs therapy from bench side to bedside.

\section{Clinical applications of MSCs}

While accumulating data have shown the therapeutic effects of MSCs in animal models of various diseases, we only focus on the clinical application of MSCs in this review. The first clinical trial using culture-expanded MSCs was carried out in 1995 and 15 patients became the recipients of the autologous cells [4]. Since then, a number of clinical trials have been conducted to test the feasibility and efficacy of MSCs therapy. By 2011/12/12, the public clinical trials database http://clinicaltrials.gov has showed 206 clinical trials using MSCs for a very wide range of therapeutic applications Figure 1). Most of these trials are in Phase I (safety studies), Phase II (proof of concept for efficacy in human patients), or a mixture of PhaseI/II studies. Only a small number of these trials are in Phase III (comparing a newer treatment to the standard or best known treatment) or Phase II /III (Figure 2). In general, MSCs appear to be well-tolerated, with most trials reporting lack of adverse effects in the medium term, although a few showed mild and transient peri-injection effects [5]. In addition, many completed clinical trials have demonstrated the efficacy of MSC infusion for diseases including acute myocardial ischemia (AMI), stroke, liver cirrhosis, amyotrophic lateral sclerosis (ALS) and GVHD.

\section{MSCs infusion to treat GVHD}

Acute graft-versus-host disease (aGVHD) occurs after allogeneic hematopoietic stem cell transplant and is

Clinical trials of MSCs are classified by disease types (by 2011/12/13 $n=206$ )
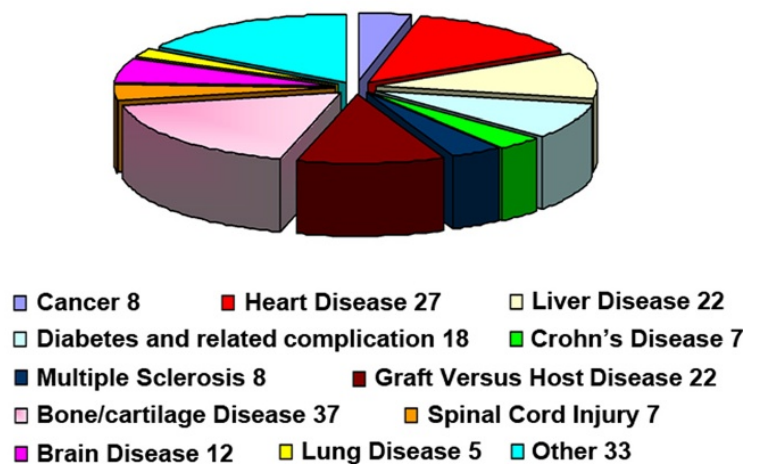

Figure 1 Clinical trials of MSCs are classified by disease types.

\section{Clinical trials of MSCs are classified by phase ( $n=187$ )}
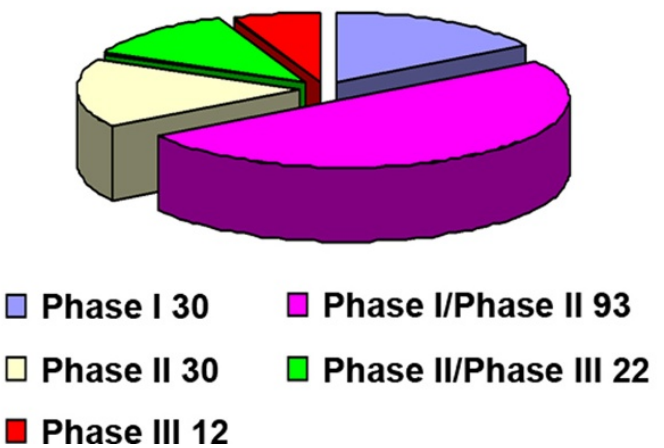

Figure 2 Clinical trials of MSCs are classified by phase.

associated with high morbidity and mortality [6-8]. Currently, corticosteroids are the gold standard for initial treatment of aGVHD. However, they are only effective for some patients. Over the past decade, the immunomodulatory functions of MSCs have triggered great interests in their application for GVHD. Le Blanc $\mathrm{K}$ et al were the first to transplant haploidentical MSCs in a 9 year old boy with severe treatment-resistant grade IV aGVHD of the gut and liver. They found the clinical response was striking and the patient was well after 1 year [9]. A subsequent study was reported by Ringdén $\mathrm{O}$ et al in 2006. They gave MSC to eight patients with steroid-refractory grades IIIIV GVHD and one who had extensive chronic GVHD. Acute GVHD disappeared completely in six of eight patients. Complete resolution was seen in gut (6), liver (1) and skin (1). Their survival rate was significantly better than that of 16 control patients. Five patients are still alive between 2 months and 3 years after the transplantation [10]. The beneficial effect of MSCs infusion was then observed in a series of studies (Table 1).

All these studies with varying numbers of patients and different degrees of GVHD severity suggest that complete and partial responses can be achieved in a majority of patients after MSCs infusion and that MSCs might represent a potential novel therapy for GVHD.

\section{MSCs for cardiovascular repair}

Despite progression of treatment options, ischemic heart disease and congestive heart failure remain major causes of morbidity and mortality. Cellular therapy for cardiovascular disease heralds an exciting frontier of research. Among the used cell types, MSCs are an attractive candidate for cardiovascular repair due to their abovementioned biological properties. In preclinical studies using experimental animal models of cardiac injury, MSCs had been show to engraft after systemic or local administration and improve the 
Table 1 A summary of the clinical experience of MSCs in GVHD treatment

\begin{tabular}{|c|c|c|c|c|}
\hline $\begin{array}{l}\text { Year of } \\
\text { publication }\end{array}$ & $\begin{array}{l}\text { Patients } \\
\text { (N) }\end{array}$ & MSC source & MSC dose & outcome \\
\hline 2007 [11] & 6 & $\begin{array}{l}\text { haplo-identical family } \\
\text { donors }(n=2) \text {, unrelated } \\
\text { mismatched donors }(n=4)\end{array}$ & $1.0 \times 10(6) / \mathrm{kg}$ & $\begin{array}{l}\text { Acute GVHD disappeared completely in five of six patients, } \\
\text { four of whom are alive after a median follow-up of } 40 \text { months } \\
\text { (range, 18-90 months) after the initiation of AMSC therapy. All } \\
\text { four surviving patients are in good clinical condition and in } \\
\text { remission of their hematological malignancy. }\end{array}$ \\
\hline
\end{tabular}

\section{8 [12] $55 \quad$ HLA-identical sibling} donors $(n=5)$, haploidentical donors $(n=18)$, third-party HLA-mismatched donors

$(n=69)$.

$1.4 \times 10(6)$ (min-max range $0.4-9 \times 10(6))$ cells per $\mathrm{kg}$

2008 [13] $7 \quad \begin{aligned} & \text { hematopoietic stem cell } \\ & \text { donors }(n=5), \text { third party } \\ & \text { parental donor }(n=2)\end{aligned}$

2009[14] $13 \quad$ Unrelated HLA disparate donors

$2009[15] \quad 33$

PBSCT combined with MSCs

From $0.5 \times 10(5)$ to $1.7 \times 10(6)$ per $\mathrm{kg}$

A median dosage of $0.9 \times 10(6) / \mathrm{kg}$ (range 0.6-1.1) to $3.0 \times 10(6)$ per $\mathrm{kg}$ based on availability

30 patients had a complete response and nine showed improvement. No patients had side-effects during or immediately after infusions of mesenchymal stem cells. Three patients had recurrent malignant disease and one developed de-novo acute myeloid leukaemia of recipient origin. Complete responders had lower transplantation-related mortality 1 year after infusion than did patients with partial or no response

One out of three patients showed slight improvement of chronic GVHD. Two patients with severe acute GVHD did not progress to cGVHD. One patient received MSC to stabilize graft function after secondary haploidentical transplantation. One patient recovered from trilineage failure due to severe hemophagocytosis.

Two patients (15\%) responded and did not require any further escalation of immunosuppressive therapy. Eleven patients received additional salvage immunosuppressive therapy concomitant to further MSC transfusions, and after 28 days, five of them (45\%) showed a response. Four patients (31\%) are alive after a median follow-up of 257 days, including one patient who initially responded to MSC treatment.

Fifteen patients (45.5\%) developed grade I-IV acute GVHD (aGVHD) and only 2 (6.1\%) developed grade III to IVaGVHD. Nine (31\%) of 29 evaluable patients experienced chronicGVHD (cGVHD).

\begin{tabular}{|c|c|c|c|}
\hline $2009[16]$ & 32 & Unrelated, unmatched donor & $\begin{array}{l}2 \text { or } 8 \text { million MS } \\
\text { in combination } \\
\text { corticosteroids }\end{array}$ \\
\hline 2010 [17] & 11 & Unrelated HLA disparate donors & $\begin{array}{l}\text { Median dose was } \\
1.2 \times 10(6) / \mathrm{kg}(\mathrm{rar} \\
0.7-3.7 \times 10(6) / \mathrm{kg})\end{array}$ \\
\hline $2011[18]$ & 12 & premanufactured, universal donor & $\begin{array}{l}8 \times 10(6) \text { cells } / \mathrm{kg} \\
\text { in } 2 \text { patients and } \\
2 \times 10(6) \text { cells } / \mathrm{kg} \\
\text { in the rest }\end{array}$ \\
\hline
\end{tabular}

Ninety-four percent of patients had an initial response $(77 \%$ complete response and 16\% partial response). No infusional toxicities or ectopic tissue formations were reported.

Overall response was $71.4 \%$, with complete response in $23.8 \%$ of cases. None patients presented GVHD progression upon MSC administration, but 4 patients presented GVHD recurrence 2 to 5 months after infusion. Two patients developed chronic limited GVHD.

7 (58\%) patients had complete response, 2 (17\%) partial response, and 3 (25\%) mixed response. Complete resolution of Gl symptoms occurred in 9 (75\%) patients. The cumulative incidence of survival at 100 days from the initiation of therapy was $58 \%$. repair of infarcted myocardium [19-21]. In a rat model of dilated cardiomyopathy, Nagaya $\mathrm{N}$ et al found that MSC transplantation significantly increased capillary density and decreased the collagen volume fraction in the myocardium, resulting in decreased left ventricular end-diastolic pressureand increased left ventricular maximum [21].

Clinical trials using MSCs to improve cardiac function have also demonstrated encouraging results. For instance, in a pilot study, sixty-nine patients who underwent primary percutaneous coronary intervention within 12 hours after onset of acute myocardial infarction were randomized to receive intracoronary injection of autologous bone marrow mesenchymal stem cell or standard saline. Several imagining techniques demonstrated that MSCs significantly improved left ventricular function [22]. We conducted a clinical trial which recruited sixty-nine patients with acute myocardial infarction after percutaneous coronary intervention (PCI). They were randomly divided into intracoronary injection of MSCs $(n=34)$ and saline $(n=35)$ groups. Three months after MSC transplantation, left ventricular ejection fraction (LVEF) in MSCs group increased significantly compared with that of pre-implantation and that of the control group [23].

Here we summarized the currently completed clinical trials registered with clinicaltrials.gov that using MSC to treat cardiovascular diseases (Table 2). While a number of studies demonstrated the therapeutic effects of MSC transplantation, the underlying mechanisms remain unclear. The beneficial effects of MSCs might be mediated not only by their differentiation into cardiomyocytes but also by their ability to secret large amounts of bioactive molecules. 
Table 2 Completed clinical trials at present time with MSC expanded in vitro (http: //clinic altrials.gov)

\begin{tabular}{|c|c|c|c|c|c|c|}
\hline Condition & $\begin{array}{l}\text { Patients } \\
\text { (N) }\end{array}$ & MSC source & Delivery route & Phase & Study design & $\begin{array}{l}\text { ClinicalTrials.gov } \\
\text { identifier }\end{array}$ \\
\hline $\begin{array}{l}\text { Myocardial } \\
\text { Ischemia }\end{array}$ & 31 & $\begin{array}{l}\text { Autologous } \\
\text { MSC from } \\
\text { bone marrow }\end{array}$ & $\begin{array}{l}\text { intramyocardial } \\
\text { injections }\end{array}$ & Phase I/II & $\begin{array}{l}\text { Non-randomized, } \\
\text { Single group assignment, } \\
\text { Open label }\end{array}$ & NCT00260338 \\
\hline $\begin{array}{l}\text { Acute } \\
\text { Myocardial } \\
\text { Infarction }\end{array}$ & 80 & $\begin{array}{l}\text { Autologous MSC } \\
\text { from bone } \\
\text { marrow }\end{array}$ & $\begin{array}{l}\text { intracoronary } \\
\text { injection }\end{array}$ & Phase II/ III & $\begin{array}{l}\text { Randomized, Parallel assignment, } \\
\text { Open Label }\end{array}$ & NCT01392105 \\
\hline $\begin{array}{l}\text { Ischemic } \\
\text { Heart } \\
\text { Disease }\end{array}$ & 48 & $\begin{array}{l}\text { MSC from } \\
\text { bone marrow }\end{array}$ & $\begin{array}{l}\text { intracoronary } \\
\text { injection }\end{array}$ & Phase I/II & $\begin{array}{l}\text { Non-Randomized, } \\
\text { Assignment, Open label }\end{array}$ & NCT00135850 \\
\hline $\begin{array}{l}\text { Heart } \\
\text { Failure }\end{array}$ & 10 & Not mentioned & $\begin{array}{l}\text { intramyocardial } \\
\text { injections }\end{array}$ & Phase II & $\begin{array}{l}\text { Randomized, Parallel Assignment, } \\
\text { Double blind (Subject, Caregiver, } \\
\text { Investigator) }\end{array}$ & NCT00927784 \\
\hline
\end{tabular}

\section{MSCs for liver disease}

In regard to liver diseases, MSCs have been used to treat cirrhosis in a limited number of patients. In a phase I trial, four patients with decompensated liver cirrhosis were included. They received autologous MSC infusion through a peripheral vein. There were no side-effects in the patients during followup. The quality of life of all four patients improved by the end of follow-up [24]. In another phase I-II clinical trial, 8 patients (four hepatitis $\mathrm{B}$, one hepatitis $\mathrm{C}$, one alcoholic, and two cryptogenic) with end-stage liver disease were included. After autologous MSCs injection, all patients tolerated well and their liver function improved, suggesting the feasibility, safety, and efficacy of using MSCs as a treatment for end-stage liver disease [25]. To test the safety and efficacy of allogenic MSCs for Patients with refractory primary biliary cirrhosis (PBC), we are conducting an open-label, multiple centers, randomized, Phase I-II clinical trial (ClinicalTrials.gov ID NCT01440309).

\section{Biological characteristics of MSCs associated with their therapeutic effects}

The use of MSCs in clinical applications requires understanding of their biological characteristics that contribute to the therapeutic effects. Currently, the following four properties are considered the most important (Figure 3): (1) the ability to home to sites of inflammation following tissue injury when injected intravenously (2) the ability to differentiate into various cell types (3) the ability to secrete multiple bioactive molecules capable of stimulating recovery of injured cells and inhibiting inflammation (4) the lack of immunogenicity and the ability to perform immunomodulatory functions. Although we divide the effects of MSCs into these four aspects for better description in this review, in fact, these four aspects are combined and overlapped. Their exact roles in the therapeutic effects of MSCs remain to be further elucidated.

\section{Capacity to migrate and engraft}

MSCs have the capacity to migrate to, and engraft in, sites of inflammation after systematic administration and exert local, functional effects in the resident tissue. Various studies have demonstrated that under a variety of pathologic conditions, MSC selectively home to sites of injury, irrespective of the tissue. Ortiz LA et al showed that murine MSCs could home to lung in response to injury, adopt an epithelium-like phenotype, and reduce inflammation in lung tissue of mice challenged with bleomycin [26]. We found that transplanted MSCs could migrate to injured muscle tissues in mdx mice [27].

Cell migration is dependent on a multitude of signals ranging from growth factors to chemokines secreted by injured cells and/or respondent immune cells [28]. Migration of MSCs may also be regulated by such signals. Studies have demonstrated that MSCs migration is under the control of a large range of receptor tyrosine kinase growth factors such as platelet-derived growth factor (PDGF) or insulinlike growth factor 1 (IGF-1) and chemokines such as CCR2, CCR3, CCR4 or CCL5 as assessed by in vitro migration assays [29].

\section{Differentiation}

MSCs have the capacity to differentiate into mesenchymal lineages including osteoblasts, adipocytes, and chondroblasts under both in vitro and in vivo conditions [30]. Studies have also reported that MSCs can give rise to cells of other lineages. We found that MSC injected immediately into C57BL/6 mice after irradiation-caused injury could differentiate into functional lung cells, such as epithelial and endothelial cells [31]. Other studies employing animal model of lung injury caused by bleomycin exposure showed that MSCs engrafted in lung differentiated into type I pneumocytes [32] and type II epithelial cells [26] or assumed phenotypic characteristics of all major cell types in lung including fibroblasts, epithelial cells, and myofibroblasts [33]. In addition, MSCs could be induced to differentiate into cells of ectoderm. For example, Kopen GC et al were the first to demonstrate that MSCs injected into the central nervous systems of newborn mice could adopt morphological and phenotypic characteristics of astrocytes and 


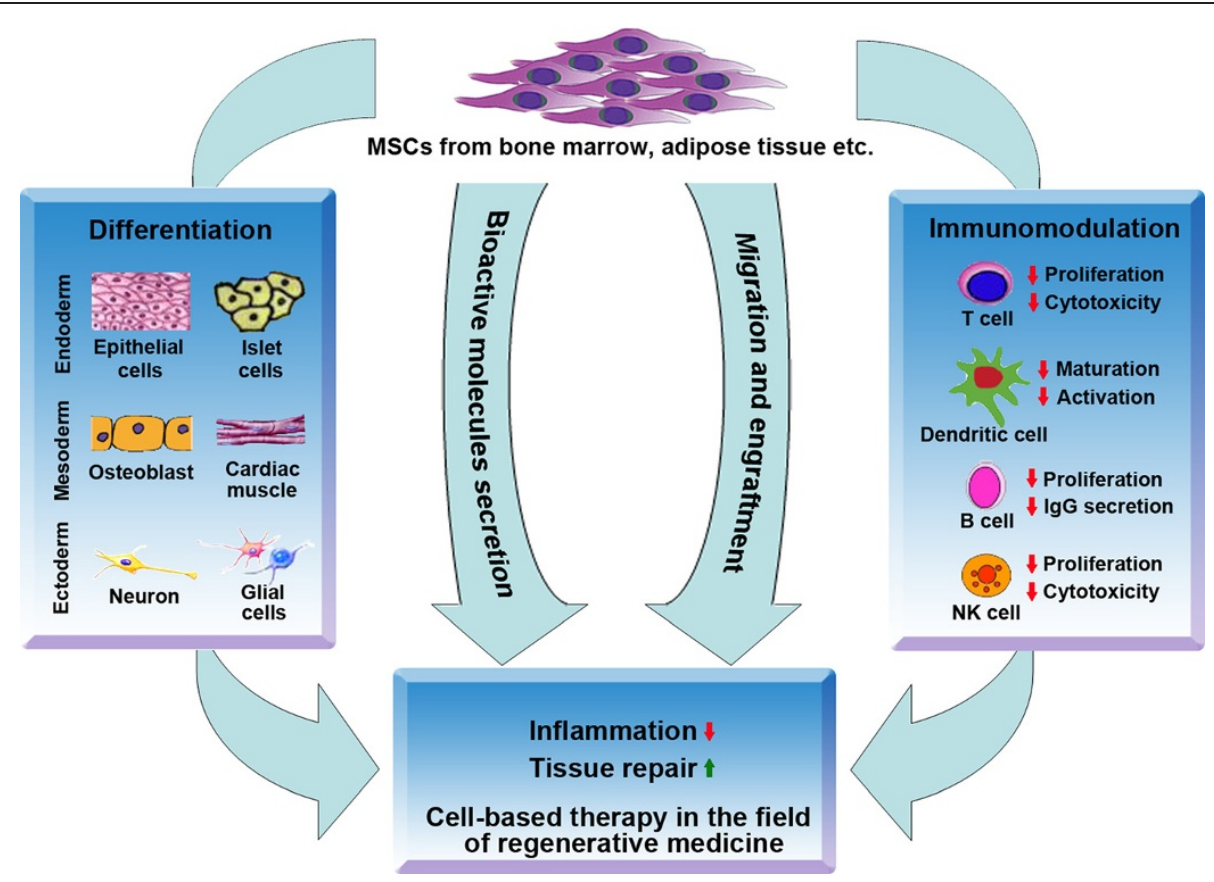

Figure 3 A schematic model demonstrating the biological properties of MSCs that are associated with their therapeutic effects.

neurons [34]. Subsequent studies confirmed such findings $[35,36]$.

The evidence that MSCs were able to differentiate into specialized cells of tissues such as epithelial cells or nervous cells, opened up the possibility of using MSCs to substitute damaged cells for disease treatment. We showed that in a C57BL/6 mouse model of ischemia-reperfusion (I/R) kidney, transplanted MSCs were able to differentiate toward renal tubular epithelium at an early stage of injury. The differentiated donor cells replaced the vacant space left over by the dead cells, therefore contributing to the maintenance of structural integrity and preceded to a subsequent tissue repair process [37]. Several studies also demonstrated the contribution of MSCs differentiation to disease treatment [27]. However, accumulating data suggest the replacement of the damaged cells by MSCs through specific differentiation may be only a small part of the mechanism underlying MSCs' therapeutic effects.

\section{Secreting multiple bioactive molecules}

MSCs could secrete multiple bioactive molecules including many known growth factors, cytokines and chemokines which have profound effects on local cellular dynamics (Table 3). Administration of conditioned medium of MSCs is able to recapitulate the beneficial effects of MSCs for tissue repair. For instance, data from Van Poll D et al provide the first clear evidence that MSCs conditioned medium (MSC-CM) provides trophic support to the injured liver by inhibiting hepatocellular death and stimulating regeneration,
Table 3 Important bioactive molecules secreted by MSCs and their functions

\begin{tabular}{ll}
\hline Bioactive molecules & Functions \\
\hline $\begin{array}{l}\text { prostaglandin-E2 } \\
\text { (PGE2) }\end{array}$ & anti-proliferative mediators [40] \\
anti-inflammation [41] \\
Interleukin-10(IL-10) & anti-inflammatory [42,43] \\
transforming growth & suppress T-lymphocyte \\
factor $\beta-1(T G F \beta 1)$, hepatocyte & proliferation [44]
\end{tabular}

growth factor(HGF)

Interleukin-1 receptor

Antagonist

human leukocyte

antigen $\mathrm{G}$ isoform (HLA-G5)

LL-37

angiopoietin-1

MMP3, MMP9

anti inflammatory [45]

anti-proliferative for naive

T-cells [46]

anti-microbial peptide and reduce inflammation [47]

restore epithelial protein permeability [48]

mediating neovascularization [49]

Keratinocyte growth factor

Alveolar epithelial fluid transport [50]

endothelial growth factor (VEGF), basic fibroblast growth factor (bFGF), placental growth factor

(PIGF), and monocyte

chemoattractant protein-1

of endothelial cells

and smooth muscle cells

[51,52]

(MCP-1) 
potentially creating new avenues for the treatment of fulminant hepatic failure (FHF) [38]. Takahashi M et al demonstrated that various cytokines were produced by BM-MSCs, and these cytokines contributed to functional improvement of the infarcted heart by directly preserving the contractile capacity of the myocardium, inhibiting apoptosis of cardiomyocytes, and inducing therapeutic angiogenesis of the infarcted heart [39].

A protein-array analysis of MSC-CM detected 69 of 174 assayed proteins and most of these detected molecules are growth factors, cytokines, and chemokines. They have known anti-apoptotic and regeneration-stimulating effects [53]. These effects can be either direct or indirect or both: direct by causing intracellular signaling or indirect by causing another cell in the microenvironment to secrete functionally active agent.

\section{Immunomodulatory functions of MSCs}

The ability of MSCs to modulate the immune system was first recognized in 2000 when Liechty KW et al found that MSCs have unique immunologic characteristics that allow their persistence in a xenogeneic environment [54]. Since then, an emerging body of data confirmed the immunomodulatory properties of MSCs. However, the precise mechanisms underlying their immunomodulation are still not fully understood. Direct cell-to-cell contact and/or release of soluble immunosuppressive factors may play major roles.

MSCs could interact with a wide range of immune cells, including $\mathrm{T}$ lymphocytes, B lymphocytes, natural killer cells and dendritic cells. A brief summary of the in vitro interaction of MSCs and immune cells was shown in Table 4. The immunomodulatory effects of MSCs have also been examined in a variety of animal models of immune diseases. For instance, donor-derived MSC could induce long-term allograft acceptance in a rat heart transplantation model [55].

The immunomodulatory functions of MSCs have generated a great amount of interest in their potential for treatment of immune disorders such as GVHD.

\section{Discussion and future directions}

Over the past decade, there have been a large number of publications on MSCs, reporting their biological properties, experimental and clinical applications or underlying molecular mechanisms. Although tremendous advancements have been made from both preclinical and clinical studies using MSCs, substantial challenges are still to be overcome before MSC therapy can fulfill its promise in wider clinical practice. (1) Safety issue: up to now, few adverse effects have been reported after MSC administration, in terms of immediate, infusional toxicity and of late effects. However, the relatively small number of patients being treated with MSCs does not allow the drawing of definitive conclusions
Table 4 Immunomodulatory effects of MSCs on immune cells

\begin{tabular}{|c|c|}
\hline $\begin{array}{l}\text { Immune cell } \\
\text { type }\end{array}$ & MSCs' effects \\
\hline \multirow[t]{3}{*}{ T lymphocyte } & $\begin{array}{l}\text { Suppress T cell proliferation } \\
\text { induced by cellular or nonspecific } \\
\text { mitogenic stimuli [44] }\end{array}$ \\
\hline & $\begin{array}{l}\text { Alter the cytokine secretion profile } \\
\text { of naive and effector T cells [56] }\end{array}$ \\
\hline & $\begin{array}{l}\text { Promote the expansion and } \\
\text { function of Treg cells [57] }\end{array}$ \\
\hline \multirow[t]{3}{*}{ B lymphocyte } & $\begin{array}{l}\text { Inhibit proliferation of B } \\
\text { lymphocyte [58] }\end{array}$ \\
\hline & $\begin{array}{l}\text { Affect the chemotactic } \\
\text { properties of B cells [59] }\end{array}$ \\
\hline & $\begin{array}{l}\text { Suppress B-cell terminal } \\
\text { differentiation [60] }\end{array}$ \\
\hline NK cell & $\begin{array}{l}\text { Alter the phenotype of NK cells } \\
\text { and suppress proliferation, cytokine } \\
\text { secretion, and cyto-toxicity against } \\
\text { HLA-class I- expressing targets } \\
{[61,62]}\end{array}$ \\
\hline \multirow[t]{3}{*}{$\begin{array}{l}\text { Dendritic cells } \\
\text { (DCs) }\end{array}$} & $\begin{array}{l}\text { Influence differentiation, maturation } \\
\text { and function of monocyte-derived } \\
\text { dendritic cells [63] }\end{array}$ \\
\hline & $\begin{array}{l}\text { Suppress dendritic cell migration, } \\
\text { maturation and antigen presentation } \\
\text { [64] }\end{array}$ \\
\hline & $\begin{array}{l}\text { Induce mature DCs into a novel } \\
\text { Jagged-2-dependent regulatory } \\
\text { DC population [65] }\end{array}$ \\
\hline
\end{tabular}

on the safety of MSCs. Furthermore, MSCs has been reported to promote tumor growth [66] and metastases [67]. Potential for malignant transformation of cultured MSC commonly used in clinical cell-therapy protocols has also been reviewed [68]. In addition, under some pathological conditions, application of MSCs might do more harm than good. We found that MSCs could aggravate arthritis in collagen-induced arthritis model by at least upregulating secretion of IL-6, which favors Th17 differentiation [69]. These studies remind us that particular attention should be paid to the biosafety of MSC. (2) Quality control: Cell amplification by culture is not free from the dangers of microbial contamination, thus bacteriological tests (mainly in liquid medium) should be carefully performed during the various phases of production and at harvest. In addition, viability and phenotype tests, oncogenicity tests and endotoxin assay should also be included. In addition, optimal timing of MSC administration, cell dose and schedule of administration need to be defined according to disease types and severity. (3)Clinical grade production: Clinical application of MSC requires a large number of cells for transplantation, so in vitro expansion of MSC is inevitable. Studies have suggested that continuous passaging of MSCs could lead to cell transformation. Rubio D et al found that human mesenchymal stem cells could undergo 
spontaneous transformation following long-term in vitro culture (4-5 months).The transformed cells exhibited chromosomal abnormalities, increased c-myc levels and telomerase activity, and formed tumours on transplantation [70]. To reduce malignant transformation of human MSCs, meticulous attention must be taken to prevent cell senescence and limit the number of passaging. According to Bernardo ME et al [71], MSCs can be safely expanded in vitro until passage 25 . We conducted the first stem cell clinical trial approved from SFDA in China and our standard procedure requires that the optimal passage should be less than passages 6 during the manufacture of MSC. MSCs used in clinical trials must be manufactured under the conditions required by Good Manufacturing Practice (GMP). (4) Autologous vs allogeneic MSCs: MSC are immune privileged because they express low levels of major histocompatibility complex-I (MHC-I) molecules and do not express MHCII molecules or costimulatory molecules such as CD80, CD86 or CD40 [15]. This unique property allows for the transplantation of allogeneic MSCs without inducing immune rejection. Thus both autologous and allogeneic MSCs can be used in the clinical setting. However, which one to prefer needs further investigation. (5) Clinical transition: In the field of MSCs research, biologists and clinicians should come together to establish proper and stringent regulations and standards for MSC based therapies. The regulations and standards should at least include methods and criteria for the culture, storage, shipping, and administration of MSCs.

MSC therapies are undergoing rapid development and have generated great excitement amongst scientists and physicians. Currently, more randomized, controlled, multicentre clinical trials are needed to find the optimal conditions for MSC therapy. We believe that eventually a novel and safe therapy with MSCs can emerge and revolutionize treatment and therapies for patients with severe diseases.

\section{Abbreviations}

MS: Mesenchymal stem cells; GVHD: Graft-versus-host-disease;

ESC: Embryonic stem cell; iPSC: Pluripotent stem cell; AMI: Acute myocardial ischemia; ALS: Amyotrophic lateral sclerosis; aGVHD: Acute graft-versus-host disease; PCI: Percutaneous coronary intervention; LVEF: Left ventricular ejection fraction; PBC: Primary biliary cirrhosis; PDGF: Platelet-derived growth factor; IGF-1: Insulin-like growth factor 1; FHF: Fulminant hepatic failure; DCs: Dendritic cells; GMP: Good manufacturing practice.

\section{Competing interests}

We declare that we have no competing interests.

\begin{abstract}
Acknowledgements
This work was supported by grants from the "863 Projects" of Ministry of Science and Technology of PR China (No. 2011AA020100); National Natural Science Foundation of China(Grant No. 30830052); The National Key Scientific Program of China(No. 2011CB964901)and Program for Cheung Kong Scholars and Innovative Research Team in University-PCSIRT(No. IRT0909).
\end{abstract}

\section{Authors' contributions}

SW drafted the manuscript; $X Q$ formatted the figures and tables, participated in manuscript revision; RCZ designed and drafted the manuscript, gave financial and administrative support. All authors read and approved the final manuscript

Received: 30 January 2012 Accepted: 16 February 2012

Published: 30 April 2012

Reference

1. Friedenstein AJ, Petrakova KV, Kurolesova Al, Frolova GP: Heterotopic of bone marrow. Analysis of precursor cells for osteogenic and hematopoietic tissues. Transplantation 1968, 6:230-247.

2. In 't Anker PS, Scherjon SA, Kleijburg-van Dder Keur C, de Groot-Swings GM, Claas FH, Fibbe WE, Kanhai HH: Isolation of mesenchymal stem cells of fetal or maternal origin from human placenta. Stem Cells 2004, 22:1338-1345

3. Dominici M, Le Blanc K, Mueller I, Slaper-Cortenbach I, Marini F, Krause D, Deans R, Keating A, Prockop D, Horwitz E: Minimal criteria for defining multipotent mesenchymal stromal cells. The International Society for Cellular Therapy position statement. Cytotherapy 2006, 8:315-317.

4. Lazarus HM, Haynesworth SE, Gerson SL, Rosenthal NS, Caplan Al: Ex vivo expansion and subsequent infusion of human bone marrow-derived stromal progenitor cells (mesenchymal progenitor cells): implications for therapeutic use. Bone Marrow Transplant 1995, 16:557-564.

5. Otto WR, Wright NA: Mesenchymal stem cells: from experiment to clinic. Fibrogenesis Tissue Repair 2011, 4:20.

6. Messina C, Faraci M, de Fazio V, Dini G, Calo MP, Calore E: Prevention and treatment of acute GvHD. Bone Marrow Transplant 2008, 41(Suppl 2):S65-70.

7. Sun ZM, Liu HL, Geng LQ, Wang XB, Yao W, Liu X, Ding KY, Han YS, Yang $H Z$, Tang BL, et al: HLA-matched sibling transplantation with G-CSF mobilized PBSCs and BM decreases GVHD in adult patients with severe aplastic anemia. J Hematol Oncol 2010, 3:51.

8. Huang XJ: Current status of haploidentical stem cell transplantation for leukemia. J Hematol Oncol 2008, 1:27

9. Le Blanc K, Rasmusson I, Sundberg B, Gotherstrom C, Hassan M, Uzunel M, Ringden $O$ : Treatment of severe acute graft-versus-host disease with third party haploidentical mesenchymal stem cells. Lancet 2004, 363:1439-1441.

10. Ringden $\mathrm{O}$, Uzunel M, Rasmusson I, Remberger M, Sundberg B, Lonnies $H_{\text {, }}$ Marschall HU, Dlugosz A, Szakos A, Hassan Z, et al: Mesenchymal stem cells for treatment of therapy-resistant graft-versus-host disease. Transplantation 2006, 81:1390-1397.

11. Fang B, Song $Y$, Liao L, Zhang Y, Zhao RC: Favorable response to human adipose tissue-derived mesenchymal stem cells in steroid-refractory acute graft-versus-host disease. Transplant Proc 2007, 39:3358-3362.

12. Le Blanc K, Frassoni F, Ball L, Locatelli F, Roelofs H, Lewis I, Lanino E, Sundberg $B$, Bernardo ME, Remberger $M$, et al: Mesenchymal stem cells for treatment of steroid-resistant, severe, acute graft-versus-host disease: a phase II study. Lancet 2008, 371:1579-1586.

13. Muller I, Kordowich S, Holzwarth C, Isensee G, Lang P, Neunhoeffer F, Dominici M, Greil J, Handgretinger R: Application of multipotent mesenchymal stromal cells in pediatric patients following allogeneic stem cell transplantation. Blood Cells Mol Dis 2008, 40:25-32.

14. von Bonin M, Stolzel F, Goedecke A, Richter K, Wuschek N, Holig K, Platzbecker U, IIImer T, Schaich M, Schetelig J, et al: Treatment of refractory acute GVHD with third-party MSC expanded in platelet lysate-containing medium. Bone Marrow Transplant 2009, 43:245-251.

15. Guo M, Sun Z, Sun QY, Han Q, Yu CL, Wang DH, Qiao JH, Chen B, Sun WJ, Hu KX, et al: A modified haploidentical nonmyeloablative transplantation without T cell depletion for high-risk acute leukemia: successful engraftment and mild GVHD. Biol Blood Marrow Transplant 2009, 15:930-937

16. Kebriaei $P$, Isola L, Bahceci E, Holland K, Rowley S, McGuirk J, Devetten M, Jansen J, Herzig R, Schuster M, et al: Adult human mesenchymal stem cells added to corticosteroid therapy for the treatment of acute graftversus-host disease. Biol Blood Marrow Transplant 2009, 15:804-811.

17. Lucchini G, Introna M, Dander E, Rovelli A, Balduzzi A, Bonanomi S, Salvade A, Capelli C, Belotti D, Gaipa G, et al: Platelet-lysate-expanded mesenchymal stromal cells as a salvage therapy for severe resistant graft-versus-host disease in a pediatric population. Biol Blood Marrow Transplant 2010, 16:1293-1301.

18. Prasad VK, Lucas KG, Kleiner GI, Talano JA, Jacobsohn D, Broadwater G, Monroy R, Kurtzberg J: Efficacy and safety of ex vivo cultured adult 
human mesenchymal stem cells (Prochymal) in pediatric patients with severe refractory acute graft-versus-host disease in a compassionate use study. Biol Blood Marrow Transplant 2011, 17:534-541.

19. Zhang S, Ge J, Sun A, Xu D, Qian J, Lin J, Zhao Y, Hu H, Li Y, Wang K, et al: Comparison of various kinds of bone marrow stem cells for the repair of infarcted myocardium: single clonally purified non-hematopoietic mesenchymal stem cells serve as a superior source. J Cell Biochem 2006, 99:1132-1147.

20. Jiang S, Haider H, Idris NM, Salim A, Ashraf M: Supportive interaction between cell survival signaling and angiocompetent factors enhances donor cell survival and promotes angiomyogenesis for cardiac repair. Circ Res 2006, 99:776-784.

21. Nagaya N, Kangawa K, Itoh T, Iwase T, Murakami S, Miyahara Y, Fujii T, Uematsu M, Ohgushi H, Yamagishi M, et al: Transplantation of mesenchymal stem cells improves cardiac function in a rat model of dilated cardiomyopathy. Circulation 2005, 112:1128-1135.

22. Chen SL, Fang WW, Ye F, Liu YH, Qian J, Shan SJ, Zhang JJ, Chunhua RZ, Liao LM, Lin S, et al: Effect on left ventricular function of intracoronary transplantation of autologous bone marrow mesenchymal stem cell in patients with acute myocardial infarction. Am J Cardiol 2004, 94:92-95.

23. Chen SL, Fang WW, Qian J, Ye F, Liu YH, Shan SJ, Zhang JJ, Lin S, Liao LM, Zhao RC: Improvement of cardiac function after transplantation of autologous bone marrow mesenchymal stem cells in patients with acute myocardial infarction. Chin Med J (Engl) 2004, 117:1443-1448.

24. Mohamadnejad M, Alimoghaddam K, Mohyeddin-Bonab M, Bagheri M, Bashtar M, Ghanaati H, Baharvand H, Ghavamzadeh A, Malekzadeh R: Phase 1 trial of autologous bone marrow mesenchymal stem cell transplantation in patients with decompensated liver cirrhosis. Arch Iran Med 2007, 10:459-466.

25. Kharaziha P, Hellstrom PM, Noorinayer B, Farzaneh F, Aghajani K, Jafari F, Telkabadi M, Atashi A, Honardoost M, Zali MR, et al: Improvement of liver function in liver cirrhosis patients after autologous mesenchymal stem cell injection: a phase I-II clinical trial. Eur J Gastroenterol Hepatol 2009, 21:1199-1205

26. Ortiz LA, Gambelli F, McBride C, Gaupp D, Baddoo M, Kaminski N, Phinney DG: Mesenchymal stem cell engraftment in lung is enhanced in response to bleomycin exposure and ameliorates its fibrotic effects. Proc Natl Acad Sci U S A 2003, 100:8407-8411.

27. Liu Y, Yan X, Sun Z, Chen B, Han Q, Li J, Zhao RC: Flk-1+ adipose-derived mesenchymal stem cells differentiate into skeletal muscle satellite cells and ameliorate muscular dystrophy in mdx mice. Stem Cells Dev 2007, 16:695-706.

28. Spaeth E, Klopp A, Dembinski J, Andreeff M, Marini F: Inflammation and tumor microenvironments: defining the migratory itinerary of mesenchymal stem cells. Gene Ther 2008, 15:730-738.

29. Yagi H, Soto-Gutierrez A, Parekkadan B, Kitagawa Y, Tompkins RG, Kobayashi $\mathrm{N}$, Yarmush ML: Mesenchymal stem cells: Mechanisms of immunomodulation and homing. Cell Transplant 2010, 19:667-679.

30. Dan YY, Riehle KJ, Lazaro C, Teoh N, Haque J, Campbell JS, Fausto N: Isolation of multipotent progenitor cells from human fetal liver capable of differentiating into liver and mesenchymal lineages. Proc Natl Acad SCi U S A 2006, 103:9912-9917.

31. Yan X, Liu Y, Han Q, Jia M, Liao L, Qi M, Zhao RC: Injured microenvironment directly guides the differentiation of engrafted Flk(+) mesenchymal stem cell in lung. Exp Hematol 2007, 35:1466-1475.

32. Kotton DN, Ma BY, Cardoso W, Sanderson EA, Summer RS, Williams MC, Fine A: Bone marrow-derived cells as progenitors of lung alveolar epithelium. Development 2001, 128:5181-5188.

33. Rojas M, Xu J, Woods CR, Mora AL, Spears W, Roman J, Brigham KL: Bone marrow-derived mesenchymal stem cells in repair of the injured lung. Am J Respir Cell Mol Biol 2005, 33:145-152.

34. Kopen GC, Prockop DJ, Phinney DG: Marrow stromal cells migrate throughout forebrain and cerebellum, and they differentiate into astrocytes after injection into neonatal mouse brains. Proc Natl Acad Sci U S A 1999, 96:10711-10716.

35. Deng J, Petersen BE, Steindler DA, Jorgensen ML, Laywell ED: Mesenchymal stem cells spontaneously express neural proteins in culture and are neurogenic after transplantation. Stem Cells 2006, 24:1054-1064.

36. Wislet-Gendebien S, Hans G, Leprince P, Rigo JM, Moonen G, Rogister B: Plasticity of cultured mesenchymal stem cells: switch from nestin-positive to excitable neuron-like phenotype. Stem Cells 2005, 23:392-402.

37. Li K, Han Q, Yan X, Liao L, Zhao RC: Not a process of simple vicariousness, the differentiation of human adipose-derived mesenchymal stem cells to renal tubular epithelial cells plays an important role in acute kidney injury repairing. Stem Cells Dev 2010, 19:1267-1275.

38. van Poll D, Parekkadan B, Cho CH, Berthiaume F, Nahmias Y, Tilles AW Yarmush ML: Mesenchymal stem cell-derived molecules directly modulate hepatocellular death and regeneration in vitro and in vivo. Hepatology 2008, 47:1634-1643.

39. Takahashi M, Li TS, Suzuki R, Kobayashi T, Ito H, Ikeda Y, Matsuzaki M, Hamano K: Cytokines produced by bone marrow cells can contribute to functional improvement of the infarcted heart by protecting cardiomyocytes from ischemic injury. Am J Physiol Heart Circ Physiol 2006 291:H886-893.

40. Bouffi C, Bony C, Courties G, Jorgensen C, Noel D: IL-6-dependent PGE2 secretion by mesenchymal stem cells inhibits local inflammation in experimental arthritis. PLoS One 2010, 5:e14247

41. Foraker JE, Oh JY, Ylostalo JH, Lee RH, Watanabe J, Prockop DJ: Cross-talk between human mesenchymal stem/progenitor cells (MSCs) and rat hippocampal slices in LPS-stimulated cocultures: the MSCs are activated to secrete prostaglandin E2. J Neurochem 2011, 119:1052-1063.

42. Nemeth K, Leelahavanichkul A, Yuen PS, Mayer B, Parmelee A, Doi K, Robey PG, Leelahavanichkul K, Koller BH, Brown JM, et al: Bone marrow stromal cells attenuate sepsis via prostaglandin $\mathrm{E}(2)$-dependent reprogramming of host macrophages to increase their interleukin-10 production. Nat Med 2009, 15:42-49.

43. Gupta N, Su X, Popov B, Lee JW, Serikov V, Matthay MA: Intrapulmonary delivery of bone marrow-derived mesenchymal stem cells improves survival and attenuates endotoxin-induced acute lung injury in mice. $J$ Immunol 2007, 179:1855-1863.

44. Di Nicola M, Carlo-Stella C, Magni M, Milanesi M, Longoni PD, Matteucci P, Grisanti S, Gianni AM: Human bone marrow stromal cells suppress Tlymphocyte proliferation induced by cellular or nonspecific mitogenic stimuli. Blood 2002, 99:3838-3843.

45. Ortiz LA, Dutreil M, Fattman C, Pandey AC, Torres G, Go K, Phinney DG: Interleukin 1 receptor antagonist mediates the antiinflammatory and antifibrotic effect of mesenchymal stem cells during lung injury. Proc Natl Acad Sci U S A 2007, 104:11002-11007.

46. Selmani Z, Naji A, Zidi I, Favier B, Gaiffe E, Obert L, Borg C, Saas P, Tiberghien $P$, Rouas-Freiss $N$, et al: Human leukocyte antigen-G5 secretion by human mesenchymal stem cells is required to suppress $T$ lymphocyte and natural killer function and to induce CD4 + CD25highFOXP3+ regulatory T cells. Stem Cells 2008, 26:212-222.

47. Krasnodembskaya A, Song Y, Fang X, Gupta N, Serikov V, Lee JW, Matthay MA: Antibacterial effect of human mesenchymal stem cells is mediated in part from secretion of the antimicrobial peptide LL-37. Stem Cells 2010, 28:2229-2238

48. Fang $X$, Neyrinck AP, Matthay MA, Lee JW: Allogeneic human mesenchymal stem cells restore epithelial protein permeability in cultured human alveolar type II cells by secretion of angiopoietin-1. J Biol Chem 2010, 285:26211-26222

49. Kim Y, Kim H, Cho H, Bae Y, Suh K, Jung J: Direct comparison of human mesenchymal stem cells derived from adipose tissues and bone marrow in mediating neovascularization in response to vascular ischemia. Cell Physiol Biochem 2007, 20:867-876.

50. Lee JW, Fang X, Gupta N, Serikov V, Matthay MA: Allogeneic human mesenchymal stem cells for treatment of $E$. coli endotoxin-induced acute lung injury in the ex vivo perfused human lung. Proc Natl Acad Sci U S A 2009, 106:16357-16362

51. Kinnaird T, Stabile E, Burnett MS, Shou M, Lee CW, Barr S, Fuchs S, Epstein SE: Local delivery of marrow-derived stromal cells augments collateral perfusion through paracrine mechanisms. Circulation 2004 109:1543-1549.

52. Kinnaird T, Stabile E, Burnett MS, Lee CW, Barr S, Fuchs S, Epstein SE: Marrow-derived stromal cells express genes encoding a broad spectrum of arteriogenic cytokines and promote in vitro and in vivo arteriogenesis through paracrine mechanisms. Circ Res 2004, 94:678-685.

53. Parekkadan B, van Poll D, Suganuma K, Carter EA, Berthiaume F, Tilles AW, Yarmush ML: Mesenchymal stem cell-derived molecules reverse fulminant hepatic failure. PLoS One 2007, 2:e941.

54. Liechty KW, MacKenzie TC, Shaaban AF, Radu A, Moseley AM, Deans R, Marshak DR, Flake AW: Human mesenchymal stem cells engraft and demonstrate site-specific differentiation after in utero transplantation in sheep. Nat Med 2000, 6:1282-1286. 
55. Popp FC, Eggenhofer E, Renner P, Slowik P, Lang SA, Kaspar H, Geissler EK, Piso P, Schlitt HJ, Dahlke MH: Mesenchymal stem cells can induce longterm acceptance of solid organ allografts in synergy with low-dose mycophenolate. Transpl Immunol 2008, 20:55-60.

56. Aggarwal S, Pittenger MF: Human mesenchymal stem cells modulate allogeneic immune cell responses. Blood 2005, 105:1815-1822.

57. English K, Ryan JM, Tobin L, Murphy MJ, Barry FP, Mahon BP: Cell contact, prostaglandin $\mathrm{E}(2)$ and transforming growth factor beta 1 play nonredundant roles in human mesenchymal stem cell induction of CD4 + CD25(High) forkhead box P3+ regulatory T cells. Clin Exp Immunol 2009, 156:149-160.

58. Augello A, Tasso R, Negrini SM, Amateis A, Indiveri F, Cancedda R, Pennesi $G$ : Bone marrow mesenchymal progenitor cells inhibit lymphocyte proliferation by activation of the programmed death 1 pathway. Eur J Immunol 2005, 35:1482-1490.

59. Corcione A, Benvenuto F, Ferretti E, Giunti D, Cappiello V, Cazzanti F, Risso M, Gualandi F, Mancardi GL, Pistoia V, et al: Human mesenchymal stem cells modulate B-cell functions. Blood 2006, 107:367-372.

60. Asari S, Itakura S, Ferreri K, Liu CP, Kuroda Y, Kandeel F, Mullen Y: Mesenchymal stem cells suppress B-cell terminal differentiation. Exp Hematol 2009, 37:604-615.

61. Sotiropoulou PA, Perez SA, Gritzapis AD, Baxevanis CN, Papamichail M: Interactions between human mesenchymal stem cells and natural killer cells. Stem Cells 2006, 24:74-85.

62. Spaggiari GM, Capobianco A, Becchetti S, Mingari MC, Moretta L: Mesenchymal stem cell-natural killer cell interactions: evidence that activated NK cells are capable of killing MSCs, whereas MSCs can inhibit IL-2-induced NK-cell proliferation. Blood 2006, 107:1484-1490.

63. Zhang W, Ge W, Li C, You S, Liao L, Han Q, Deng W, Zhao RC: Effects of mesenchymal stem cells on differentiation, maturation, and function of human monocyte-derived dendritic cells. Stem Cells Dev 2004, 13:263-271.

64. Chen L, Zhang W, Yue H, Han Q, Chen B, Shi M, Li J, Li B, You S, Shi Y, et al: Effects of human mesenchymal stem cells on the differentiation of dendritic cells from CD34+ cells. Stem Cells Dev 2007, 16:719-731.

65. Zhang B, Liu R, Shi D, Liu X, Chen Y, Dou X, Zhu X, Lu C, Liang W, Liao L, et al: Mesenchymal stem cells induce mature dendritic cells into a novel Jagged-2-dependent regulatory dendritic cell population. Blood 2009, 113:46-57.

66. Djouad F, Plence P, Bony C, Tropel P, Apparailly F, Sany J, Noel D, Jorgensen C: Immunosuppressive effect of mesenchymal stem cells favors tumor growth in allogeneic animals. Blood 2003, 102:3837-3844.

67. Karnoub AE, Dash AB, Vo AP, Sullivan A, Brooks MW, Bell GW, Richardson AL, Polyak K, Tubo R, Weinberg RA: Mesenchymal stem cells within tumour stroma promote breast cancer metastasis. Nature 2007, 449:557-563.

68. Prockop DJ, Brenner M, Fibbe WE, Horwitz E, Le Blanc K, Phinney DG, Simmons PJ, Sensebe L, Keating A: Defining the risks of mesenchymal stromal cell therapy. Cytotherapy 2010, 12:576-578.

69. Chen B, Hu J, Liao L, Sun Z, Han Q, Song Z, Zhao RC: Flk-1+ mesenchymal stem cells aggravate collagen-induced arthritis by up-regulating interleukin-6. Clin Exp Immunol 2010, 159:292-302.

70. Rubio D, Garcia-Castro J, Martin MC, de la Fuente R, Cigudosa JC, Lloyd AC, Bernad A: Spontaneous human adult stem cell transformation. Cancer Res 2005, 65:3035-3039

71. Bernardo ME, Zaffaroni N, Novara F, Cometa AM, Avanzini MA, Moretta A, Montagna D, Maccario R, Villa R, Daidone MG, et al: Human bone marrow derived mesenchymal stem cells do not undergo transformation after long-term in vitro culture and do not exhibit telomere maintenance mechanisms. Cancer Res 2007, 67:9142-9149.

doi:10.1186/1756-8722-5-19

Cite this article as: Wang et al:: Clinical applications of mesenchymal stem cells. Journal of Hematology \& Oncology 2012 5:19.

\section{Submit your next manuscript to BioMed Central and take full advantage of:}

- Convenient online submission

- Thorough peer review

- No space constraints or color figure charges

- Immediate publication on acceptance

- Inclusion in PubMed, CAS, Scopus and Google Scholar

- Research which is freely available for redistribution

Submit your manuscript at www.biomedcentral.com/submit
Ciomed Central 